\title{
SOBRE UMA FOTOGRAFIA DE GUERRA: fronteiras do fotojornalismo contemporâneo
}

\author{
Juliana Leitão
}

Este artigo debate sobre fotografia de guerra. Uma imagem capturada por André Liohn ${ }^{15}$ e premiada internacionalmente gera um debate sobre fronteiras na fotografia, estética no fotojornalismo, linguagem fotográfica e ética jornalística. Debate-se também com a história da fotografia de guerra e pode-se traçar uma relação desta imagem com outras imagens.

A fotografia feita e premiada por Liohn e as informações dadas pelo fotógrafo, em abril de 2012, para o programa Roda Viva ajudaram no debate sobre as fronteiras na imagem documental. Essa entrevista se deu pelo fato do fotógrafo brasileiro ganhar um dos mais importantes prêmios de guerra, o Robert Capa Gold Medal. As fotografias premiadas foram tiradas na Líbia. Entre os entrevistadores, o outro fotógrafo de guerra Maurício Lima, o editor de fotografia da Folha de São Paulo, João Weiner e o editor de fotografia do Estado de São Paulo, Eduardo Nicolau.

O Robert Capa Gold Medal é um prêmio dado pela Overseas Press Club of America (OPC) e premia desde 1955 "best published photographic reporting from abroad requiring exceptional courage and enterprise". A Overseas Press Club of America foi fundada em 1939 em Nova York por um grupo de correspondentes estrangeiros. Segundo o site oficial da OPC, eles procuram manter uma associação internacional de jornalistas que trabalham nos Estados Unidos e no exterior para incentivar os mais elevados padrões de integridade profissional e habilidade na comunicação de notícias, para ajudar a educar uma nova geração de jornalistas, de contribuir para a liberdade e independência de jornalistas e da imprensa em todo o mundo, e para trabalhar em direção a uma melhor comunicação e compreensão entre as pessoas (OPCOFAMERICA).

Iniciamos então o debate com as perguntas que nortearam a pesquisa para este trabalho:

1. O que pode ser definido como fotografia de guerra e o que a diferencia das outras fotografias? 
2. Fotografia, vídeo e fotograma: novas fronteiras no fotojornalismo de guerra?

3. Existe um limite ético/estético na fotografia de guerra?

4. Fotografia e pintura de Guerra: imagens próximas ou distantes dentro do campo visual?

\section{O que pode ser definido como fotografia de guerra e o que a diferençia das outras fotografias?}

A fotografia de guerra, tal e qual a conhecemos hoje tem como seu primeiro e mais importante representante Andrei Friedmann, mundialmente conhecido como Robert Capa. No prefácio de Ligeiramente fora de foco (2010:15) Cornell Capa escreveu: "Meu irmão, Robert Capa, assumiu o encargo de registrar o inferno que o homem criou para si próprio, a guerra".

Trazemos o debate para esse momento da história da fotografia em que a guerra começou a ser coberta como se faz hoje. O historiador Richard Whelam resgata um depoimento de John Hersey sobre Capa que diz que além de humanidade, coragem, bom gosto, Capa possuía uma "atitude dura quanto à técnica gratuita" (CAPA, 2010, p.26). Robert capa além de ficar conhecido por suas imagens, ficou também sobre suas ideias sobre fotografia, a famosa frase: "Se suas fotos ainda não estão boas o suficiente, é porque você ainda não está perto o suficiente" (CAPA, 2010, p.15).

Sempre um defensor da foto tecnicamente imperfeita, daí o título de seu livro, ligeiramente fora de foco, $\mathrm{Capa}^{16}$ é imprescindível neste debate por causa de inegável proximidade com a imagem de André Liohn.

Existe um personagem central em uma cobertura, que irá olhar, pensar e sob circunstâncias extremas registrar histórias, relatar uma guerra através de imagens. Jean Gallard traz o debate sobre a proximidade: "O olho do fotógrafo está perigosamente próximo. Está, por assim dizer, com o nariz colado nos detalhes" (GALARD, 2012, p.101).

Leão Serva traz no Observatório da Imprensa os riscos da atividade:

Guerras matam muitos jornalistas. Mas, entre eles, fotógrafos e cinegrafistas são as principais vítimas. E a proporção cresceu nos últimos tempos. Relatório da ONG internacional Comitê para a Proteção de Jornalistas aponta que $40 \%$ dos jornalistas mortos em ação em 2011 eram fotógrafos ou cinegrafistas, o dobro da média histórica apurada desde 1992. Ao produzir suas imagens, muitas vezes os repórteres fotográficos se expõem a riscos. Até mesmo jornalistas de texto ou de voz estão convictos de que os

|||||||||||||||||||||||||||||||||||||||||||||||||||||||||||

16 Robert Capa. Disponível em Magnum Photos: <http://www.magnumphotos.com/C.aspx?VP3=CMS3\&V-F=MAGO31_10_VForm\&ERID=24KL535353> Acesso 11 de junho de 2013. 
de imagem são os mais valentes, como escreve David Halberstam em Requiem, homenagem aos 135 fotógrafos que perderam a vida na mesma guerra do Vietnã que matou Capa: "Nós, jornalistas de texto, sempre soubemos que os fotógrafos eram realmente os corajosos. Só existe uma forma de eles produzirem intimidade com a cena: serem testemunhas oculares" (SERVA, 2012).

A fotografia de guerra, é um tipo de cobertura de notícias que não se assemelha muito às outras, existe o risco de vida, que está diretamente ligado ao enfoque e ao ângulo de visão, como explica Goffman (2012:547): "Por trás do herói que corre riscos pode haver um cinegrafista capaz de administrar estas dificuldades, bem com uma câmera. Seja como for, o ângulo de onde ele efetivamente filma limita-se aos ângulos de onde ele pode filmar e daí a existência de um viés". A ética profissional, a postura e as intenções desses fotógrafos e fotógrafas de guerra são muito mais cobradas pelo público, cobradas porque as situações são talvez mais extremas, porque a visibilidade é maior. Em Beleza Exhorbitante, Galard fala em escrúpulos:

As coletâneas de fotografias de guerras, de fomes, de desastres de todo tipo, os catálogos de exposições e outros álbuns sobre esses temas começam pela evocação dos escrúpulos que os fotógrafos tiveram no exercício de sua profissão e pela exposição de motivos que os levaram a superar tais escrúpulos (GALARD, 2012, p.117).

Leão Serva traz uma discussão técnica, estética e ética, a tríade de um debate sobre cobertura de guerra a partir das escolhas de Capa:

Ao aplicar sua concepção teórica, Capa recusava as teleobjetivas, preferindo as lentes de $50 \mathrm{~mm}$, que os fotógrafos chamam de "lente normal" por ser a que melhor reproduz o ângulo de visão do homem. A $50 \mathrm{~mm}$ capta a imagem de objetos que estão em um campo de $45^{\circ}$ à frente, muito semelhante ao campo de visão do olho humano. Mais longas, as teles só deixam entrar a imagem de objetos que estão num pequeno campo de visão. Por isso eles parecem tão ampliados: porque uma pequena fração da imagem ocupará toda a foto. Uma tele de $600 \mathrm{~mm}$ tem um campo visual de apenas $4^{\circ}$. Esse "afinamento" provoca outro efeito: a perspectiva se desfaz, some a percepção das diferentes distâncias dos objetos, tudo o que aparece na foto parece estar à mesma distância. A tele "chapa" o fundo, como acontece com a visão de um homem que vê com um só olho. Ao dizer que uma foto é boa quando feita de perto, portanto, Capa elabora um conceito estético, mas também técnico, a partir da geometria, em busca do que considera a perspectiva "verdadeira". Sua ideia tem também uma decorrência ética: se a foto feita de longe distorce a posição dos elementos, ela 
fere o princípio de fidelidade do jornalismo (SERVA, 2013).

A cobertura às vezes é feita por somente uma pessoa, como nesses conflitos a guerra está espalhada por toda uma região, os fotógrafos, cinegrafistas nem sempre estão juntos. Imagem premiada de André Liohn foi feita quando ele estava sozinho, o prêmio inclusive deu-se por causa dos riscos corridos pelo fotógrafo. O que torna o relato daquele fato vindo de uma única fonte, o que Goffman debate da seguinte forma: "A informação concernente a um acontecimento precisa às vezes ser extraída inteiramente daquilo que é retransmitido por um indivíduo, que é o único canal disponível” (GOFFMAN, 2012, p.57). O autor está debatendo sobre a vulnerabilidade dos mundos relatados, já que "um indivíduo que retransmite uma ocorrência através de si mesmo está, evidentemente, em posição de editar aquilo que ele retransmite" (GOFFMAN, 2012, p.547).

Sádaba debate a teoria do enquadramento a partir desse enfoque, desse marco, framing dado pelo jornalista:

Tanto el periodista como individuo con unas características concretas, como el periodista en cuanto profesional que trabaja con unas rutinas y una determinada organización, hacen que los hechos adquieran encuadres diferentes en los distintos medios (SÁDABA, 2008, p.14).

A teoria do enquadramento coloca o papel do repórter como figura central que irá traduzir, observar, relatar alguns aspectos do acontecimento que se transformará em notícia: "El trabajo del periodista permite mirar al mundo desde un lugar, en cierto modo, privilegiado. Cuenta con fuentes, medios técnicos y acceso a muchos acontecimientos cotidianos [...] A este lugar se refiere la teoría del framing" (SÁDABA, 2008, p.21).

O fotógrafo, as agencias, os jornais, os editores podem possuir discursos diferentes sobre uma mesma imagem e quem esteve lá e vivenciou precisa esclarecer as circunstâncias e o processo da construção daquela imagem.

Um exemplo para este debate é o trazido por Greg Marinovich no livro Clube do Bang Bang que relata as experiências de quatro fotógrafos que cobriram os conflitos na África do Sul nos anos 90:

\begin{abstract}
A foto tinha causado sensação ${ }^{17}$. Estava sendo usada em pôsteres para arrecadar fundos para organizações de assistência. Tinha sido publicada em jornais e revistas do mundo inteiro, e a reação imediata do público fora dar donativos para qualquer organização humanitária em operação no Sudão. A imagem de partir o coração de uma criança faminta e indefesa sendo observada por
\end{abstract}

||||||||||||||||||||||||||||||||||||||||||||||||||||||||||||||||

17 Foto: Kevin Carter, premiada pelo Pulitzer, 1994. Disponível em: <http://www.pulitzer.org/awards/1994> Acesso 11 de junho de 2013. 
um abutre levara, inevitavelmente, à pergunta "O que aconteceu com a garotinha?", seguida de perto por "O que o fotógrafo fez para ajudá-la?”. A artilharia de perguntas tinha começado a afetar Kevin. Não podia responder que simplesmente deixara a criança lá, que a criança não correra nenhum risco de morrer de fome, pois o centro de distribuição de alimentos, capaz de ministrar nutrição de emergência, estava a meros cem metros de distância. Primeiro Kevin contou que enxotou o abutre, foi embora e se sentou embaixo de uma árvore para chorar. Não sabia o que havia acontecido com a criança. Mas, as perguntas continuaram e ele começou a elaborar a história, dizendo que tinha visto a criança se levantar e andar na direção da clínica. Isso atenuou muitos dos receios das pessoas, porém não eliminou o dilema moral de Kevin: depois de tirar a foto, porque simplesmente não pegou a menina no colo e não a levou para o centro a poucos metros dali? Seu trabalho como jornalista, de mostrar o sofrimento dos sudaneses tinha sido feito e até bem demais. A verdade é que a Operação Socorro ao Sudão não tinha levado Kevin e João até lá para recolherem ou alimentarem crianças, e sim para mostrarem o pior da fome e da guerra, para gerar publicidade. Mas, as perguntas prosseguiam (MARINOVICH, 2003. P. 196-197).

Outro aspecto da guerra é o seu espetáculo, um acontecimento distante da realidade de quem consome essas notícias sobre conflitos em países que pouco se sabe, a televisão que cobre ao vivo, o fotógrafo que fotografa e envia imediatamente a imagem, sem dar tempo ao debate e à análise, o fato de estar sendo mostrado no momento do acontecimento, muda a relação que se estabelece com aquela notícia, acontece uma relação de entretenimento. Para Goffman:

Acontecimentos que não têm nenhuma incidência real em nossas vidas ou uma incidência muito eventual podem ser facilmente utilizados como recurso para um enredo. Ao que parece, uma maneira de abafar acontecimentos reais é dar-lhes cobertura ao vivo. Assim sendo, poder-se-ia apresentar vários argumentos de tipo socialmente responsável sobre a dramatização do mundo e nossa consequente vacinação contra tudo. Não penso que nos transformamos subitamente em espectadores passivos, que exigem que o mundo se nos apresente de tal modo que possamos ficar temporariamente encantados por um espetáculo e por trás dessa orientação na vida estejam anunciantes e políticos providenciando a entrega vantajosa de experiência indireta, de segunda mão. Acredito que sempre estivemos a deixar-nos cativar (GOFFMAN, 2012, p.661). 
Se pensarmos em uma cobertura feita por poucos, às vezes uma imagem específica foi captada sem que nenhum outro jornalista estivesse perto, como foi o caso da foto do abutre e da menina no Sudão de Kevin Carter, ganhadora de um prêmio Pulitzer nos anos 90. A pessoa que foi enviada aquele local, distante de sua cultura, vai registrar para os "seus" aquela guerra.

Erving Goffman pensa sobre o enquadramento que pode ser dado a um acontecimento, o autor diz que a pergunta "o que está acontecendo aqui?" é bastante suspeita já que os acontecimentos podem ser descritos com enfoques e perspectiva diferentes, assim como por pessoas que na cena possuem papéis diferenciados:

Em certo sentido, aquilo que para o golfista é jogo para o caddy é trabalho. Interesses diferentes produzirão - na expressão de Schutz - relevâncias motivacionais diferentes. (Além disso, a variabilidade é complicada aqui pelo fato de que aqueles que trazem perspectivas diferentes para os "mesmos" acontecimentos estão propensos a empregar aberturas e níveis de enfoque diferentes) (GOFFMAN, 2012, p.31).

Ele complementa com uma ideia interessante:

Falar de algo que acontece diante dos olhos dos observadores significa situar-se em terreno mais firme do que é habitual nas ciências sociais; contudo o terreno é ainda movediço e continua de pé a questão crucial de como se chegou a um aparente acordo a respeito da identidade de "algo" e da abrangência da expressão "diante dos olhos" [...] Nesse sentido tem-se argumentado, por exemplo, que os torcedores rivais num jogo de futebol não vivenciam o "mesmo" jogo (GOFFMAN, 2012, p.32).

No trabalho de campo de um repórter fotográfico é importante salientar que a dedicação, as circunstâncias e a prática mesmo do/a profissional depende da possibilidade de tempo para entrar naquelas histórias e contá-las para o mundo:

O repórter fotográfico foi ao local, no meio das populações flageladas. Fez seu trabalho, que consiste em fixar imagens de ruínas, de crianças esquálidas, refugiados em fuga, corpos mutilados. Realizou sua missão: informar, fazer saber, testemunhar. Foi aos quatro cantos do mundo, percorreu o planeta. É um batalhador. Arriscou sua vida. Viveu o inferno. Ele deve ser persistente. Mas, uma divisão dos papéis e uma distinção de temperamentos logo se impõem. O profissional da reportagem-relâmpago envia a suas agências imagens da atualidade mais recente. Estava no lo- 
cal antes dos concorrentes, voltou antes de todo mundo. Ele pula de uma guerra a outra, de um helicóptero a outro. Só trabalha com recursos digitais, envia suas imagens via satélite. Alguns fotógrafos, ao contrário, decidem trabalhar com calma, tornar-se disponíveis (Sebastião Salgado, James Nachtwey, Stanley Greene) (GALARD, 2012, p.117,118).

Trata-se de um dilema na fotografia que se preocupa em noticiar e que possui uma demanda de cobertura em tempo real ou o mais próximo disto. Existem decisões circunstanciais, pessoais, profissionais, culturais, etc., que somente quem está em campo tomando decisões em meio a uma situação extrema pode tomar e pode se responsabilizar por tê-las tomado:

O fotógrafo deve decidir sobre a distância que vai colocar entre o objeto e a câmera, sobre a relação mais ou menos estreita, mais ou menos flutuante, entre o objeto e o enquadramento da foto [...] acepção ao mesmo tempo ética e estética da boa distância, em que a distância exata consiste em não estar nem perto demais (até a representação sensacional e inspirada pela compaixão dos indivíduos que sofrem) nem longe demais (na indiferença estetizante diante de vítimas anônimas), o pudor, o respeito, a exatidão, a justeza são preocupações partilhadas por outros que não os fotógrafos [...] Dever-se-ia introduzir um pouco de apreensão, senão de temor e de tremor, na arte de calcular a distância exata a manter entre o olhar e seu objeto, entre o espectador e sua representação, nem que fosse, justamente, por causa dessa apropriação (GALARD, 2012, p.144).

E quando não as toma, recebe ordens, direcionamento por meio de pautas, ligações de editores então, que isso fique claro, na pós-produção, nas legendas, nos textos explicativos, o processo, pode ser assim desvelado. Até porque aquela imagem é uma interpretação dada por seu autor ou autora "O ato fotográfico é um ato interpretativo" (GALARD, 2012, p.127).

E trazendo o debate sobre o prêmio de uma fotografia de guerra, Galard traz questões sobre o que se premia exatamente, "E se as listas dos laureados e dos prêmios e as antologias as apontam como "as melhores"? Como uma foto pode ser a melhor do ano?" (GALARD, 2012, p.115) “O que é uma foto 'bem sucedida' quando, faz muito tempo, a nitidez não é mais indispensável e a imperfeição não é depreciatória?” (GALARD, 2012, p.115).

No site Fotografe uma ideia, Liohn resume um pouco o seu pensamento sobre a fotografia de guerra e seu papel nesse processo de construção de opiniões sobre aquele conflito:

A urgência do conflito, que coloca nas mãos de quem o vive sempre um binômio que mudará sua vida a partir dali. Lutar ou 
correr, viver ou morrer. E todas as consequências dos atos impostos pela guerra, e o direito de vida retirado violentamente. $\mathrm{E}$ o objetivo do fotógrafo é justamente este. Elucidar na sociedade através de seus documentos audiovisuais, reflexões e posições críticas frente aos embates da guerra, violência, e direitos humanos e todas as bifurcações que seguem estes temas (http://fotografeumaideia.com).

\section{Fotografia, vídeo e fotograma: novas fronteiras no fotojorna- lismo de guerra?}

A foto icônica da cobertura de guerra que André Liohn fez da guerra da Líbia é o fotograma de um filme. Dubois levanta a questão do estatuto do que se chama "fotogramas" de filme:

Objetos irresolúveis e perturbadores e, por essa razão, exemplares da filosofia da exposição. O fotograma como núcleo dialético, remetendo a um objeto, sendo dois objetos ao mesmo tempo, um objeto que não é nem (realmente) cinema nem (simplesmente) fotografia, que é um pouco mais que uma foto (vai além dela) e um pouco menos que cinema (vem aquém). $\mathrm{O}$ impossivel fotograma, ao mesmo tempo condição primeira de aparecimento do filme (sem ele, não existe imagem projetada possível), mas também sua negação em ato (já que ver um fotograma de filme, um único, por si mesmo, é necessariamente não ver o filme como tal, como imagem-movimento projetada sobre tela; relação de exclusão: ver um deles interdita a visão do outro), o fotograma, única imagem real do dispositivo-cinema (tangível, tocável, palpável - como uma foto) e, no entanto, imagem por natureza inapreensível durante a projeção (virtual, fictícia, ilusória, inacessível, intocável - como um sonho) (DUBOIS, 2004, p. 232,233).

Na entrevista do Roda Viva (2012) João Weiner, explica que hoje em dia existem câmeras $4 \mathrm{k}^{18}$ das quais se extrai de um vídeo em alta resolução uma foto equivalente a uma imagem de uma câmera de 14 megapixels, e complementa: "mas isso muda completamente o conceito de fotografia, da espera do clique"

André Liohn responde:

Eu não estou ali fotografando, a minha fotografia não tem valor nenhum como fotografia, eu não estou ali defendendo a minha fotografia, não estou ali fazendo arte, não estou ali pensando se

18 Uma câmera que filma mais do que full HD e chama-se 4k porque se aproxima de 4 mil pixels. 
alguém vai gostar ou alguém vai pensar que a minha fotografia virou um ícone da guerra, nada, nada. Estou ali para mostrar o que aconteceu com aquele homem. Esse homem, o nome dele é Hamid Shwaili, ele tinha 28 anos de idade, era um mecânico desempregado forçado a lutar para defender a cidade, a família dele. Eu voltei com essa imagem, eu voltei com esse vídeo, qualquer coisa daquela imagem o nome dele o lugar eu garanto [...]. Eu paro de filmar, fotografo, continuo filmando... Eu não acho que minha foto, meu vídeo, muda nada na vida daquela pessoa ali, aquela pessoa morreu defendendo a cidade dela de um criminoso que não deveria existir. Eu como André fazendo aquela imagem posso estar aqui hoje dizendo o que aconteceu, basta (RODA VIVA, 2012).

Para Dubois “o fotograma em si é, portanto, a própria encarnação da ideia de articulação, de dobra entre foto e cinema, é o ponto exato (punctum) de passagem entre eles, é o objeto sonhado de abolição dos limites entre os dois territórios” (2004, p.233).

A pergunta do editor de fotografia do Estado de São Paulo, Eduardo Nicolau a André Liohn traz uma resposta de quem não se preocupa com esses limites: "Quando você decide filmar ou fotografar provavelmente deve ser o mesmo equipamento?".

É a mesma máquina, hoje você tem essas máquinas que dão essa possibilidade [...]. A minha fotografia é só uma desculpa para eu poder estar ali participando daquilo tudo ali e de alguma forma opinando sobre aquilo que está acontecendo. E se eu posso participar de uma forma mais ampla fotografando e filmando ao mesmo tempo então melhor ainda. São situações em que eu obviamente vejo, talvez seja mais óbvio para mim que o filme conta melhor. [...] Eu vejo que aqui o filme conta melhor a história. Eu sabia que ali havia um começo, um meio e oxalá um fim. E o filme é obviamente melhor para isso (RODA VIVA, 2012).

Depois o editor do Estadão enfatiza: "Se você não tem uma boa foto, você filma tranquilamente?" André Liohn responde: “Tranquilamente".

Dubois em Efeito filme: figuras, matérias e formas do cinema na fotografia reúne artistas que trabalham na fronteira do que seria cinema e do que seria fotografia e tem-se assim um híbrido, que o autor chama de figura:

O efeito filme, tal como ele opera hoje nas obras e no método de inúmeros criadores contemporâneos. O efeito filme é tanto uma questão de imagem (um problema visível nas imagens) quanto de dispositivo (uma maquinação invisível, mas pensada, tangendo ao processo: a luz, a tela, a projeção, o transporte, a textura, a vibração, a trajetória); tanto uma questão de percepção quanto de 
intelecção; tanto de sensação quanto de emoção (DUBOIS, 2004, p.230).

Este debate sobre técnica fotográfica existe desde a existência da fotografia, os seus limites, seu campo de atuação e suas fronteiras sempre foram demarcados, o que atualiza essa discussão é a tecnologia que força toda uma comunidade fotográfica a se adaptar, a repensar sua linguagem, o suporte que vai receber essa imagem ou esse vídeo, que não se limita mais à capa do jornal ou ao editorial da revista.

\section{Existe um limite ético/estético na fotografa de guerra?}

Para André Liohn existe sim, enquanto o fotógrafo não se preocupa com o fato de captar imagens em movimento e imagens fixas e ter premiado um fotograma que não tem momento do click, não tem o instante decisivo e instintivo do momento certo, ele se preocupa com a defesa de que não faz arte, de que conta histórias por meio da fotografia, fazendo parte de um grupo de fotógrafos e pensadores sobre a fotografia que acreditam que existe uma fronteira ética que deve ser preservada.

André Liohn diz na entrevista:

Tem gente que me manda uma fotografia. O que quer que eu responda? Não escreve nada sobre ele, ou por que ele fotografa. Fotografia não é mais nada do que uma desculpa. Não tem valor nenhum se não tiver uma ligação, um comprometimento, não sei como explicar isso. O fotógrafo que quer ser fotógrafo eu não entendo. Eu não entendo fotografar como profissão (RODA VIVA 2012).

O fotógrafo entrevistado enfatiza: "Eu estou ali, não estou pensando em fotografia. De jeito nenhum. Fotografia não passa na minha cabeça um segundo" ele complementa: "eu não estou pensando, agora estou fazendo a foto perfeita ou icônica".

Quando surgem as perguntas, "Você não tem que fazer o foco, o enquadramento?" ou as afirmações: "uma das suas fotos da escadaria é tecnicamente complexa... você pensa". André Liohn rebate: "Eu sei fotografar. É como o cara que sabe dirigir, ele não pensa agora tenho passar a marcha, tenho que ligar a seta... ele faz e no caminho de a-b, ele pensa na namorada que ele vai encontrar...". Um entrevistador diz: "você trabalha com instinto". Por fim, André Liohn completa sua resposta: "eu sei o que eu quero e como eu quero fotografar meu foco é no manual, porque o foco automático não é tão rápido como eu gostaria, eu aumento o ISO e diminuo o ISO ali, sempre fotografo com f10, profundidade alta, porque eu garanto que algum foco tem"19 (RODA VIVA, 2012).

||||||||||||||||||||||||||||||||||||||||||||||||||||||||||||||

19 Refere-se ao diafragma da lente que quanto mais fechado, como é o caso de F10, mesmo entrando menos 
O fotógrafo Mauricio Lima pergunta: "Que tipo de influência o Robert Capa teve na sua fotografia e sendo o prêmio que você ganhou?"

André Liohn responde: "Nenhuma, nem conhecia o Robert Capa".

Mauricio Lima cita o livro Ligeiramente fora de foco de Robert Capa:

No livro ele disse que a fotografia de conflito tem que ser ligeiramente fora de foco, que eu acho que seja para transmitir as sensações ali do fotógrafo naquelas circunstâncias. Um pouco subexposta - ou seja, a foto não tem que estar perfeita tecnicamente para mostrar o medo e angústia e a agonia de uma maneira mais subliminar (RODA VIVA, 2012).

A fotografia de guerra sempre esteve sob os olhares preocupados de quem as observa, imagens de conflitos, mortos, violência sempre exigiram explicações, críticas e debates calorosos sobre limites. Traremos aqui algumas dessas discussões:

Sobre a Fotografia de Miki Kratsman: Migrant Worker, Ariella Azoulay diz que o corpo deitado no chão em silêncio fica exposto ao fotógrafo que usa seu tempo para compor um enquadramento dramático. A autora levanta vários questionamentos: O fotógrafo não deveria ter feito essa foto do corpo exposto, abandonado, sem estar coberto ou seria seu dever fazer essa imagem, para chamar nossa atenção sobre a passagem do tempo entre o acidente e alguém se dar ao trabalho de honrar a morte e cobrir o corpo como é de costume? Para esta autora a legenda suscinta: "Trabalhador Migrante" que o fotógrafo anexa à fotografia, quando ele mais tarde apresentou-a em um museu, ele se tornou o fotógrafo portador da queixa. Esta queixa não é da pessoa fotografada, mas da cena fotografada ou evento: a desapropriação da cidadania, que o ato fotográfico se colocou contra (AZOULAY, 2008, p119-121).

Existem diversos debates sobre os limites éticos quando se trata de fotojornalismo e fotodocumentação, a cor é um deles, a autora Mary Marien trouxe em Photography, a cultural history (2007) um capítulo que tem um título "A cor de preocupação" em que debate o fato de o trabalho em preto-e-branco continuar a ser associado à seriedade de propósito, embora se possa argumentar que o filme colorido equivale ao modo como vemos o mundo. A autora resgata que décadas de fotografia amadora, e a ampla utilização de cores em publicidade, fez parecer muito fácil e muito emocional para temas sombrios como a guerra e o sofrimento humano. Além disso, o aumento do uso de filme colorido em fotografia de arte levou a associação de cor com a fabricação, fantasia e auto-expressão. Documentaristas e fotógrafos que trabalham a cor foram acusados de adulterar o meio, tornando a fotografia parecida com uma pintura. A profusão de fotografia a cores sinalizou a perda da gravidade ética e o abandono da ideia de que a fotografia pode desempenhar um papel na mudança social (MARIEN, 2007, p.422).

luz no sensor da câmera existe maior profundidade campo, mais elementos em foco. 
Um fotógrafo que está sempre no meio desse fogo cruzado sobre ética e estética na cobertura fotográfica documental é Sebastião Salgado. Marien (2007: 426) diz que embora ninguém abertamente tenha acusado Salgado de construir a sua reputação nas costas do que é infeliz, alguns observadores consideram ofensivas as impressões radiantes, porque parecem sugerir que a miséria é a maneira imutável do mundo, ou que uma presença divina vai enobrecer aqueles que sofrem. Uma das mais enfáticas debatedoras sobre o trabalho de Salgado é Susan Sontag no seu livro: Diante da dor dos outros (2003). A primeira crítica trazida por Sontag é a seguinte:

Um retrato que se exime de designar seu tema torna-se cúmplice, ainda que inadvertidamente, do culto da celebridade que inflamou um apetite insaciável pelo tipo oposto de fotografia: assegurar só aos famosos a menção de seus nomes rebaixa aos demais a exemplos representativos de suas ocupações, de suas etnias, de suas aflições [...] Tiradas em 39 países, as fotos de migrações de Salgado reúnem, sob esse único título, uma multidão de causas e de modalidades de infortúnio diversas. Fazer o sofrimento avultar, globaliza-lo, pode incitar as pessoas a sentir que deveriam "importar-se" mais. Também as convida a sentir que os sofrimentos e os infortúnios são demasiado vastos, demasiado irrevogáveis, demasiado épicos para serem alterados, em alguma medida significativa, por qualquer intervenção política local (SONTAG, 2003, p.68).

Crítica que Gallard (2012:120) rebate, diz que:

ele comete um erro, por exemplo em não indicar, em legenda, os nomes das pessoas que fotografa. Mas, quem faz isso? Suas fotos, carregadas de poder emblemático e alegórico, são desprovidas de função explicativa. Mas, que fotografia poderá algum dia explicar o que mostra?

Talvez a grande problemática recaia sobre o fato de que a miséria, a vulnerabilidade de alguém está sendo colocada como prêmio, exposição, preço. Sontag diz que: "As fotos objetificam: transformam um fato ou uma pessoa em algo que se possa possuir. E as fotos são uma espécie de alquimia, a despeito de serem tão elogiadas como registros transparentes da realidade" (SONTAG, 2003, p.69).

Essa discussão não é nova, FABRIS (2011), ao falar sobre a fotografia e artes visuais no período das vanguardas históricas, resgata os embates na aceitação da fotografia como arte, Franz Höllering em 1920 incita o uso da câmera como arma: "O fotógrafo proletário deve criar documentos de sua época, não banalidades inúteis [...]” (FABRIS, 2011, p.137). Höllering não aconselha a prática da fotomontagem pelo operariado: "Höllering exorta o trabalhador a dedicar-se à fotografia pura, sem perder a tempo com pretensões artísticas descabidas, que o distanciariam da 'grande ideia do socialismo"' (FABRIS, 2011, p.149). 


\section{Fotografia e pintura de guerra: imagens próximas ou distantes dentro do campo visual?}

O debate sobre os limites estéticos na cobertura de guerra parece algo específico da cobertura fotográfica jornalística, carregada de simbolismos por utilizar um instrumento mecânico que faz com que o referente pareça mais palpável, é o "isso foi” de Barthes na Câmara Clara (1984) e que Dubois debate em O Ato Fotográfico, dizendo que existem alguns perigos com relação a esse referente que adere:

1. o fato da fotografia atestar a existência do objeto não pode ser confundida com uma explicação de sentido. A foto não explica, não interpreta, não comenta. O índice para com o "isso foi" não preenche com um "isso quer dizer".

2. a ideia de mensagem sem código é somente aquela fração de segundo entre o momento de fotografar e a revelação da imagem. Somente aí quando a luz que emana do objeto e deixa a impressão na película que o homem não intervém.

3. convém libertar bem o signo fotográfico desse fantasma de uma fusão com o real. No espaço, a imagem como signo está separada do que representa e no tempo separa o agora do então. A foto nos remete a uma imagem tanto exterior quanto anterior. $\mathrm{O}$ princípio de distância espaço-temporal vem em contraponto ao princípio indiciário da proximidade física (DUBOIS, 1998, p. 83).

Para este debate, trazemos a imagem emblemática de Goya: Três de Maio de 1808, onde mostra a invasão francesa à Espanha, com a qual encontramos algumas similaridades à imagem de Liohn. A pintura possui uma espécie de licença para ser obra de arte, para usar a estética, para se preocupar com luz, perspectiva, proporção e até mesmo usar isso como elemento principal de uma obra que trate de mortes, guerras, miséria. A fotografia parece não possuir a mesma licença, precisa se justificar, explicar, debater porque não registra mecanicamente sem interferir, como se isso fosse possível. A fotografia, especificamente o fotojornalismo tem data, nomes, evidências, depoimentos. Os autores de manuais didáticos sobre fotojornalismo sempre questionam a fronteira entre uma foto ilustrativa "sem obrigatoriedade de ser documental" e as fotos "que se pretendem realistas" (OLIVEIRA, 2009, p.114). Um debate que poderia estar superado se sobre o fotojornalismo não houvesse um peso de realismo que é cobrado como uma obrigação.

Sontag fala de fotografia de guerra, de olhar imagens a partir de uma ótica, dos direitos à estetização na fotografia e traz um debate sobre o impacto do trabalho de Goya:

As imagens de Goya comovem o espectador quase ao ponto do horror. Todos os ornamentos do espetacular foram suprimidas: a paisagem é uma atmosfera, uma escuridão, apenas ligeiramente esboçada. A guerra não é um espetáculo. E a série de gravuras 
de Goya não é uma narrativa: cada imagem, legendada por uma breve frase que deplora a iniquidade dos invasores e a monstruosidade do sofrimento que infligiram, se sustenta de forma independente dos demais. O efeito cumulativo é devastador (SONTAG, 2003, p.40).

Sobre essa relação entre fotografia de guerra e pintura de guerra Galard diz que: "Apesar de Jacques Callot, apesar de Goya, seria possível acreditar que se perpetuou uma verdadeira cegueira ante os horrores da guerra. Hoje, o horror é superexposto como se fossem necessários novos meios para produzir a mesma cegueira" (2012, p.103). E traz um trecho sobre as crises existentes entre a fotografia de guerra e a estética da pintura, as distâncias existentes a partir do relato de um dos mais famosos fotógrafos de guerra McCullin:

Sua intenção nunca foi realizar obras de arte. Suas fotografias são documentos, "não ícones". Ele quer produzir documentos que talvez evitem a repetição de tais horrores. A respeito de uma reportagem em Sabra e Chatila, nega que tenha cedido a um acréscimo artístico ou a uma projeção cultural "Não é culpa minha se a luz de Sabra e Chatila tinha algo de bíblico, se as cenas que ali se desenrolavam pareciam desenhadas por Goya" (GALARD, 2012, p.133).

Nesse depoimento de McCullin percebe-se uma preocupação em não ter colocado a arte por cima dos fatos, preocupação que André Liohn também trouxe, e que são acusações que Salgado há anos se defende, eles aparecem no centro de uma discussão sobre fronteiras porque decidiram fazer fotografia e não pintura, como fez Goya.

\section{Algumas conclusões}

As perguntas que iniciaram o ensaio não possuem respostas objetivas e muito menos definitivas para esse debate, mas as problematizações feitas a partir do que foi dito por todos esses pensadores da fotografia e da cobertura de guerra feita por Liohn possibilitam constatar que a fotografia passa por grandes modificações, os limites são muito mais amplos e o seu poder de atuação extravasa aqueles dados a ela.

A fotografia de guerra está sendo feita em preto e branco e em cores fortes e contrastantes, em vídeo e em imagem fixa, tanto habilmente calculada e nítida como borrada e incerta, forçando o que está posto como o que "deve" ser feito. Os prêmios, que guiam o trabalho da maioria dos fotógrafos, têm aceitado até imagens de celulares, ditas "amadoras". Podemos, talvez, vislumbrar um novo lugar para a fotografia de guerra, um espaço que ela está ocupando e que é novo, mesmo trazendo consigo velhos problemas, 
que existem desde a sua invenção e que parece que não está perto de terminar. Talvez aí resida o seu mistério, o seu embate entre ser mecânica, entre poder ou não ser artística, em lidar com emoções, em ter um referente que adere independente das discussões que é resultado de um olhar, de uma interpretação, de um recorte e de um enquadramento.

As aparentes semelhanças com a linguagem visual da pintura não permite que sejam assimiladas da mesma forma, o fotojornalismo provoca a comoção de espectadores e críticos porque a caixa escura, o jogo ótico e o tal "click" automático fazem com que ela se disfarce de imparcial. A característica mecânica da fotografia a torna, em muitos debates simplórios sobre ela, um problema grave no que se refere à manipulação, como se a credibilidade estivesse na imagem somente, que se torna uma janela aberta sem mais.

\section{Referências}

AZOULAY, Ariella. The civil contract of photography. New York: Zone Books, 2008.

BARTHES, Roland. A Câmera clara: nota sobre a fotografia. Rio de Janeiro: Nova Fronteira, 1984. 185p.

BERGER, P.L., LUCKMANN T. La construcción social de la realidade. Amorrortu editores. Buenos Aires, 1997.

CAPA, Robert. Ligeiramente fora de foco. Cosac Naify. São Paulo, 2010. 296p.

DUBOIS, Philippe. O Ato fotográfico e outros ensaios. Tradução de Marina Appenzeller. Campinas, SP: Papirus, $2^{\mathrm{a} e d}$ 1998. 362p.

. Efeito filme: figuras, matérias e formas do cinema na fotografia. In: SANTOS, Alexandre; SANTOS, Maria Ivone. (Orgs.). A Fotografia nos processos artísticos contemporâneos. Porto Alegre: UFRGS, 2004.

FABRIS, Annateresa. O Desafio do olhar: fotografia e artes visuais no período das vanguardas históricas. São Paulo: Editora WMF Martins Fontes, 2011. 233p

FOTOGRAFE uma ideia. Disponível em: http://fotografeumaideia.com.br/site/index. php?option=com_content\&task=view\&id=2129\&itemid=137. Acesso em janeiro de 2013.

FREUND, Gisèle. Fotografia e sociedade: comunicação e Linguagens 2a edição. 1995. 214p.

GALARD, Jean. Beleza exorbitante: reflexões sobre abuso estético. Editora FAP-UNIFESP. São Paulo-SP. 2012, 176p

GOFFMAN, Erving. Os Quadros da experiência social: uma perspectiva de análise. Petrópolis, RJ: Vozes. 2012. 692p. 
MARIEN, Mary. Convergences. 1975 to the present. In: Photography, a cultural history. London: Prentice Hall, 2007.

MARINOVICH, Greg, Silva, João. Clube do Bangue-Bangue. São Paulo: Companhia das Letras. 2003

OPCOFAMERICA. Disponível em: http://opcofamerica.org/awards/robert-capa-gold-medal-award-2011. Acesso em 10 de julho de 2012.

RODA VIVA. Entrevista ao fotógrafo Andre Liohn 30/04/2012. Disponível em: http:// tvcultura.cmais.com.br/rodaviva/roda-viva-andre-liohn-30-04-2012. Acesso em 10 de julho de 2012.

SÁDABA, TERESA. Framing: el encuadre de las noticias. El binomio terrorismo-medios. La crujía, Buenos Aires, 2008, 252 pp.

SERVA, Leão. O Mandamento de Robert Capa. Edição 681. Disponível em: http:// www.observatoriodaimprensa.com.br/news/view/_ed681_o_mandamento_de_robert_ capa14/02/2012. Acesso em 27/01/2013.

SONTAG, Susan. Diante da dor dos outros. São Paulo: Companhia das Letras, 2003. 